Article

\title{
"Such Fictitious Evil Spirits": Adriaan Koerbagh's Rejection of Biblical Demons and Demonic Possession in A Light Shining in Dark Places (1668)
}

\author{
Ismael del Olmo \\ History Department, Faculty of Philosophy and Letters, University of Buenos Aires, Buenos Aires C1406CQJ, \\ Argentina; delolmoismael@hotmail.com
}

Received: 13 March 2019; Accepted: 15 April 2019; Published: 19 April 2019

\begin{abstract}
This paper traces Adriaan Koerbagh's interpretation of biblical devils and scriptural instances of demonic possession in his 1668 Een Ligt Schijnende in Duystere Plaatsen (A light shining in dark places). Koerbagh's book is a radical exponent of the early Dutch Enlightenment, and its views on demonology are of importance if we want to assess the extent to which traditional scholastic pneumatology was challenged in the second half of the XVIIth century. This paper will also address Thomas Hobbes' positions regarding demons and demonic possession in Leviathan (1651), given that Hobbes' interpretations were fundamental to Koerbagh's own positions. We will focus on the Hobbesian exegetical strategies of etymology, naturalization, and metaphorization, which helped Koerbagh to point at diseases, evil thoughts, figures of speech, or human enemies as plausible explanations for scriptural passages concerning devils and possession. But we will also see that Koerbagh's Cartesian definition of spirits led him to a more radical stance than that of Hobbes: demons do not exist at all. This paper will end by claiming that Koerbagh's interpretation of Christian demonology both as a remnant of Pagan and Jewish superstitions, and a knowledge indifferent to salvation - themselves Hobbesian principles-went hand in hand with his attempt to secularize the biblical text. Thus, the devil, once a part of the sacred truth, could now be seen as a fragment of a human cultural heritage.
\end{abstract}

Keywords: Adriaan Koerbagh; demonology; demonic possession; biblical exegesis; Thomas Hobbes

\section{The Late XVIIth-Century Attack on Demonology}

It is a well-known fact that the Reformed minister Balthasar Bekker (1634-1698) committed an intellectual arson with his De Betoverde Weereld (The World Bewitched), published in four volumes between 1691 and 1693, and soon translated into French, English, and German. A controversial tour de force around the subject of demonology, the book may well be the most comprehensive critique of the idea of the devil ever written. Arguing from a hyper-providentialist stance-belief in God's absolute power was threatened by the supposed power of the devil, and even by angelic mediators-the book includes attacks on demonic possession, sorcery, witchcraft, counter-magic, and traditional beliefs about spirits; it also offers a comparative approach towards world demonologies. In order to deactivate the power of the devil in the material realm, De Betoverde Weereld accepts the Cartesian separation of mind and body and the concomitant principle of the impossibility of the interaction between thought and extension (pineal glanded humans excepted). Bekker supported his claims through Revelation. The Scripture is adamant in its claim that Satan was defeated and chained in Hell, and has no power over worldly events. Bekker's book thus re-interpreted the key biblical passages involving demons and their operations under a dissident exegetical light, suggesting metaphors, figures of speech, Hebrew and Greek etymologies, and natural explanations to account for purported demonic 
entities and activities (Vermeir 2013; Van Bunge 2000; Van Ruler 2000; Fix 1999; Israel 1996; Fix 1989; Attfield 1985). Undoubtedly, Bekker helped to accelerate a trend already present in early modern intellectual circles: the degradation of scholastic demonology as sheer superstition (Cameron 2010, pp. 264-69). His ideas were discussed in contemporary circles in a full-scale debate, and rejected by religious institutions-Bekker, accused of scandal and heresy, was denied communion and suspended from his ministry. It has been said that his views on the demonic even had an impact on popular culture; hence, Bekker could be credited for extending his proto-Enlightenment teachings outside the scholarly world (Wielema 2004, pp. 53-78).

One of the many contributions to the debate around Bekker's book was a 1691 anonymous Dutch poem, which refers to Bekker as one "whose intellect challenges the power of the devil" (wiens brein des Duyvels macht betwist). The author proposed an ironic "justification" (onschuldiging), stating that "you cannot blame this teacher for the texts he has written" (Geen schult kan men dees Leeraar geven/Van't geen dat hy heeft uytgeschreven), "because he cannot even speak for himself" (Door dien hy selfs niet spreken kan). It is clear who was at fault here: the "company of cunning heretics" (Een party ketters vol van list) whose works Bekker had read. Who were they? Among other names, the author lists "Hobbes" and "Spinosa" (Anonymous 1691, p. 7). ${ }^{1}$

Most likely, the poet is thinking about Leviathan (1651), Thomas Hobbes' (1588-1679) masterpiece. Although Elements of Law (1640) already offers a discussion about "angels good and evil", Hobbes devotes this brief account mainly to his rejection of the scholastic notion of incorporeal substances (Hobbes 1928, pp. 42-43). It is only in his influential Leviathan that Hobbes writes several chapters arguing at length against the early modern biblical and philosophical interpretation of the devil-we will develop these points later in the article. ${ }^{2}$ With regards to Baruch Spinoza (1632-1677), the reference is unclear: we are certain that the poet was not aware of the 1661 Short Treatise, an unpublished manuscript in which an entire chapter questions the existence of the devil (Spinoza 2002, pp. 98-99). Was the poem referring, then, to Spinoza's Theological-Political Treatise (1670), in which the biblical "evil spirit" is taken as the human passion of hatred and melancholy? (Spinoza 2007, p. 22). Was the poet thinking about Spinoza's famous letters to Hugo Boxel in the last months of 1674, where the philosopher attacked the belief in ghosts, apparitions, and incorporeal spirits? (Spinoza 1995, pp. 261-79). Or is

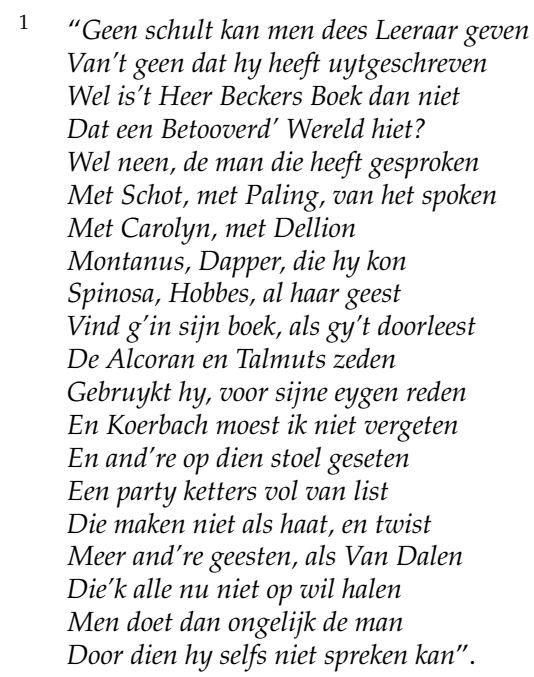

I would like to express my deep gratitude to Wendy Wauters (Katholieke Universiteit Leuven) for translating this passage. The anonymous reviewer of the article has also given valuable insight on the meaning of the poem. On another note, the anti-demonological influence of many of the authors considered in this poem, such as Abraham Palingh and Antonius Van Dale, is analyzed in. (Waite 2018)

2 For Hobbes' understanding of demons and its impact, see, among others, (Del Olmo 2018; MacMillan 2014; Bath and Newton 2006; Schaffer 1985; Jobe 1981). 
the poem addressing Spinoza's reply to Albert Burgh in 1675, in which the excommunicated Jew accuses Burgh of fearing the Prince of Darkness, and thus, to have fallen in the hands of superstition? (Spinoza 1995, pp. 340-44). Be it as it may, it is clear that Hobbes and Spinoza were perceived as declared enemies of Christian demonology and thus as legitimate forerunners of Balthasar Bekker.

The Dutch poet also adds this brief note to the list of Bekkerian influences: "I must not forget Koerbach" (En Koerbach moest ik niet vergeten) (Anonymous 1691, p. 7). This is Adriaan Koerbagh (1632-1669), one of the most intriguing figures of the early Dutch Enlightenment (Salatowsky 2017; Israel 2001, pp. 185-96; Wielema 2003a, pp. 571-74; 2003b, 2001). The poem could be alluding to Een Blomhof van allerley lieflijkheyd (A flower garden of all sorts of loveliness), published in February 1668. Organized as a dictionary, the book translates and analyses what Koerbagh calls "bastard words" in Hebrew, Greek, Latin and French, which were used daily in the practice of Law, theology, and medicine. Koerbagh portrays the book as an attack on what he perceived as the language of the elite, designed to deceive ordinary people. Here, he rejected the early modern idea of the devil in one short entry, "Duyvel" (Koerbagh 1668, pp. 258-59). But Adriaan's most important contribution to the intellectual history of demonology, and the one we will study in this paper, is Een Ligt Schijnende in Duystere Plaatsen (A light shining in dark places), finished also in 1668 (Koerbagh 2011; Van Bunge 2011, pp. 1-38). ${ }^{3}$ Arguably one of the most radical texts of the early modern period, it contained among other dissident ideas an elaborated diatribe against the devil and demonology.

Koerbagh, a doctor of medicine and law, entered Spinoza's inner circle at the beginning of the 1660 's, sharing with its members the critique towards the scriptural and political foundations of revealed religions and Christian confessions. A light shining in dark places, an outspoken radical work, poured scorn on the irrationality of organized religious beliefs, labeling them as sheer superstitions. As with his A flower garden, the book was devised as a tool for the philosophical enlightenment of the people and to this end, it was written in Dutch and in a straightforward style-fatal mistakes that Spinoza would never make ("caute"). ${ }^{4}$ Due to the scandal that arose with A flower garden, the book, labeled as "atheisticum" in Reformed circles, was suppressed in Amsterdam and confiscated in Utrecht (Israel 2001, p. 190)—Koerbagh fled to the autonomous county of Culemborg. He carried with him the manuscript of his new oeuvre. After working through almost 180 pages of $A$ light shining in dark places, an increasingly horrified printer at Utrecht alerted the local officials about Koerbagh's manuscript. Word soon reached Amsterdam, and its authorities issued a warrant, seized the runaway Adriaan in Leiden, brought him back to Amsterdam, interrogated him, and condemned him in July 1668 to ten years in prison under the charge of blasphemy. He lasted a little more than one year, dying in October 1669. Censorship was brutal: only two copies of $A$ light shining in dark places survive today, presumably those the authorities used to build up the case (Nadler 2011, pp. 38-51).

It seems clear that, in his search for Bekker's influences, the anonymous Dutch poet was trying to identify the main suspects involved in what Jonathan Israel has called "the death of the devil" (Israel 2001, p. 375). It is hard to know whether such demonicide was ever perpetrated, as belief in devils and demonology continued in the late modern period and beyond (Gijswijt-Hofstra et al. 1999). But there is no doubt that during the second half of the XVIIth century, reaching a peak with Bekker's contribution, the medieval and early modern idea of the Enemy was under heavy fire. Given that the science of devils was deeply entwined with exegetical tradition, scholastic physics and metaphysics,

3 There is doubt about the involvement of Adriaan's brother, Johannes Koerbagh (1634-1672), a theologian, in the writing of the book (Wielema 2004, p. 85; Israel 2001, p. 195).

4 Indeed, Wielema claims that Koerbagh's works "are certainly far more outspokenly anti-Christian than anything Spinoza ever dared to write. In addition, Koerbagh wrote purposely in Dutch in order to enlighten not just the academic elite but, more importantly, the common people as well" (Wielema 2004, p. 85). Let us remember that Spinoza published his Theological-Political Treatise anonymously and in Latin, and the place of publication and the name of the printer were false ("Hamburgi, apud Henricum Künraht"). Furthermore, after the scandal brought by the book, he did not publish anything else. This is one of the main reasons why Antoine Lilti has challenged Israel's view of Spinoza as the origin of the "radical" Enlightenment (Lilti 2009; Israel 2001). 
and crystalized assumptions about the power of the Christian churches and its heralds, anti-demonic attacks had obvious implications at the level of Biblical exegesis, natural philosophy, theology, and politics-or, following Spinoza's perceptive terminology, at the theologico-political level. In this paper, I aim to trace these implications by focusing on one particular vignette of the crusade against the early modern devil: the views on evil spirits and demonic possession found in Koerbagh's A light shining in dark places. To my knowledge, there is no detailed study on this subject. A thorough consideration of Koerbagh's anti-demonological positions will be useful to assess the extent to which traditional early modern pneumatology - that is, the scholarly notions on spirits, their ontology, their powers over causality, and the ways they interacted with bodies-was rejected in the early Enlightenment.

In searching for Koerbagh's views on the devil and demonic possession, we will have the opportunity to assess the influence of Thomas Hobbes, one of the main figures among those anti-demonological "cunning heretics" mentioned by the Dutch poet. Koerbagh knew Leviathan well, as Gerrit Jongeneleen has made clear in his systematic research on Hobbes' impact on Adriaan's thought (Jongeneelen 1991). In fact, Leviathan is the only contemporary book from which Koerbagh openly quotes; furthermore, he had a close friendship with its translator into Dutch, Abraham van Berkel, also a member of Spinoza's clique (Wielema 2017). ${ }^{5}$ It is known that, England excepted, the Dutch Republic was the territory in which Hobbes' works exerted their greatest influence (Malcolm 2002, pp. 27-52). And this influence seems crucial to the radicalism of the Dutch Enlightenment: as an author has put it, Hobbes was "the fountainhead of intellectual contamination and religious heterodoxy in the second half of the seventeenth century" (Champion 2012, p. 95). Highlighting Hobbes' presence in Koerbagh's demonology would be in line with Noel Malcolm's critique of Israel's concept of "radical Enlightenment" essentially as a Spinozist and underground phenomenon. As Malcolm suggests, one should not despise changes within mainstream theology, mainstream metaphysics, and mainstream psychological and moral theory, changes that could lead to radical reactions; in this sense, between Spinoza and Hobbes, the latter was the most influential of the two in the European intellectual landscape (Malcolm 2002, pp. 535-37). ${ }^{6}$

Did Hobbes influence Koerbagh's anti-demonological arguments? And if he did, to what extent? On the one hand, we shall see that Hobbes seems to have had an important impact on Koerbagh's anti-demonological exegesis, which includes a radical etymological interpretation of the names and words traditionally attached to the Christian evil spirit ("Satan", "Abaddon", "devil", "angel"), and the naturalization and metaphorization of biblical devils and instances of demonic possession. We will encounter this Hobbesian imprint again in our conclusion, when evaluating Koerbagh's claim regarding the Pagan origins of demonology, and his rejection of devils as utterly irrelevant in matters concerning salvation.

Nevertheless, on the other hand, it seems clear that Koerbagh surpassed Hobbes in his radicalism. Concerning anti-demonological arguments, Jonathan Israel does indeed mention Hobbes as a main influence on the XVIIth-century's skepticism towards devils. But he adds that "proceeding several steps further, from the 1660s, the founding fathers of philosophical radicalism initiated their campaign, negating Satan, spirits, and supernatural forces altogether in complete defiance of received ideas" (Israel 2001, p. 375). We may place Koerbagh among those whom proceeded "several steps further". This is a direct consequence of different metaphysical frames. Hobbes' critique of evil spirits is part of his attack on the notion of "incorporeal substances", an essential element of scholastic pneumatology. Hobbes argues that, together, these terms imply an outright contradiction: substances, as part of the res of the universe, occupy space. Spirits exist, but they are subtle and invisible bodies, like the air and the

5 In order to escape trial after the scandal caused by A flower, Koerbagh fled to Culemborg, where he joined Van Berkel, already in hiding after his controversial Dutch edition of Leviathan in 1667. Furthermore, Van Berkel assisted Koerbagh in reading proofs for A light shining in dark places, and tried to convince the printer in Utrecht-who would eventually alert the authorities about the book—to finish the job (Israel 2001, p. 190; Van Bunge 2001, p. 101).

6 For Malcolm's debate with Israel, see (Springborg 2004). 
vital spirits. Furthermore, Hobbes had to admit that Scripture forces us to acknowledge not only that spirits exist, but that there are such things as evil spirits (Hobbes 2012, pp. 7, 207, 210-11, 214, 371-73).

I consider, then, that Jongeleen misses the point when, searching for Hobbes' influence on Adriaan, he affirms: "Comme Hobbes, Koerbagh nie l'existence d'esprits spirituels: ce qu'on appelle un mauvais esprit n'est rien d'autre que le Vice qui empêche le soutien divin de s'effectuer" (Jongeneelen 1991, p. 257). The first part of the sentence is correct: Hobbes denies that there are "spiritual spirits"; but he does not reduce the "mauvais esprit" to vice: they could also be substances. On the contrary, as we shall see below with more detail, Koerbagh took a more radical stance. He made use of a Cartesian definition of spirit: "a spirit consists in thought", or, alternatively, "a spirit is a thinking thing". Being pure thought, disembodied spirits could never act on matter (Koerbagh 2011, pp. 59, 61; Wielema 2003b, p. 73). Thus, Koerbagh's metaphysics shows that the Christian devil, a substantial entity with will and capacity to intervene in the material world, is an error. This is a depart from Hobbes' anti-demonology, a depart connected with Koerbagh's Cartesian philosophy, but also with his views on Revelation: whereas Leviathan affirms that Scripture forces us to acknowledge demons as substantial beings, A light shining in dark places went on to deny that demons were part of Revelation. It remains true that, in order to support these claims when discussing demons in the Scripture, Koerbagh deployed the exegetical weapons of etymology, and the naturalization and metaphorization of devils and their activities, strategies which Leviathan had systematized more than a decade earlier. But these were now pointing in a more radical direction than Hobbes imagined (or dared to affirm): denying the very existence of evil spirits.

The conclusion will underline Koerbagh's emphasis on the rejection of demonology as a pernicious Pagan doctrine, alien to Christianity's true message. This went hand in hand with what, for lack of a better term, we may refer to as a strong secularizing effort on Koerbagh's part: he insists that several biblical passages are better understood in light of natural reason and natural causality, debunking previous claims to supernatural or demonic causalities. As stated above (and as we will argue below), Hobbes may have inspired Koerbagh's view, according to which these passages hold no importance whatsoever to men's salvation. In this line, I will conclude this text mentioning what it seems to me to be the driving force behind Koerbagh's views on devils and demoniacs: the understanding of (part of) the Scripture not as sacred truth but as cultural heritage.

\section{2. "We Rightly Reject the Fabricated Evil Spirits": Explaining Away Spirits and Demons}

Adriaan Koerbagh frames his arguments against demonology as an attack on the affinities between organized Christianity and superstition. This diatribe stems from A light shining in dark places's approach towards "rational religion". Abandoning the true knowledge of God, theologians and their flocks "have fallen from a rational religion to a religion full of superstitions, fictions and fabrications". This is often due to the difficulty of Scripture itself, worsened by the ignorance of those in charge of understanding and explaining it. Indeed, "the errors and fallacies of the divines in theology and religion" are due to "the obscurity and confusion of Scripture, further increased by false interpretation" (Koerbagh 2011, pp. 47,219$)$. In this section, we shall analyze one crucial element of this blend of irrational religion, false exegesis, and theological ignorance: the devil.

It has been noticed that Koerbagh thought that an important metaphysical fiction pervading religions was the belief in the existence of incorporeal and spiritual entities capable of operating in the material world (Wielema 2003b, p. 72). Hence, our discussion on Koerbagh's devils must tackle his views on pneumatology. In this line, it is striking to learn that Koerbagh published a Spinozist book before Baruch Spinoza had the chance to deliver his philosophy to the printing press-in fact, during his trial, Koerbagh was asked if his metaphysical ideas derived from Spinoza's "pantheism", and if he 
shared his interpretation of the Bible with the excommunicated Jew (Van Bunge 2011, pp. 28, 32). ${ }^{7}$ A light shining in dark places affirms that God is a simple, unique, eternal, infinite Being with two known attributes, thought and extension. This Being, the only substance, is all in all, "so all that one sees, hears and feels is nothing but a mode of being dependent on this Being". Now, this Being has often been misunderstood, even by the authors of Scripture. John 4: 24, for example, states that "God is spirit". But the Apostle "does not say or explain what a spirit is or what is the nature of a spirit". On a footnote, Koerbagh gives the Greek etymology for the word "spirit" (pneuma) as "breathing, blowing, emitting wind, giving off smell". It is clear, then, that if the Greeks portray God as a spirit, they "never knew what a spirit is". And what is it? As we have seen above, Koerbagh defines it in a Cartesian way: "a spirit consists in thought", "a spirit is a thinking thing" (Koerbagh 2011, pp. 59, 61).

This critique of the traditional notion of "spirit" is of obvious importance for the book's understanding of devils. Koerbagh highlights that the Christian Church is very interested in the subject of demonology, and "the theologians insist that we believe in evil spirits". He refuses to comply: "I deny that there are such fictitious evil spirits as the clergy say there are" (Koerbagh 2011, pp. 235, 425). As we saw in the introductory section, his opposition is philosophical, given that Cartesianism indicates that a disembodied spirit cannot act on matter. In this line, Koerbagh states, for example, that "it is said of the invented evil spirits" that they seduce people, or even kill them, actions that "do not belong to a spirit". But they do take place amidst human beings, who are spirit and body. Thus, "evil spirits" should not be considered as "independently existing spirits" or entities "outside the human domain"; often, it is "a human being who is someone else's evil spirit". Alternatively, if not human enemies, these "evil spirits" could be understood as "evil thoughts" and inner dispositions: we can be seduced to all kinds of evil and be led to "a disquiet and unhappy state" by ignorance, desire for money, yearning for status, and immoderation. Given that these things "exist in our souls, which are spirits ( ... ) , one may call them, although not quite accurately, spirits". In conclusion, for Koerbagh the "evil spirits" must be seen as "twofold, physical and spiritual": one's own thoughts and dispositions, and one's own human enemies (Koerbagh 2011, pp. 429, 451, 453). As we will see, this definition opens the door to the naturalization and metaphorization of evil spirits and spiritual distress.

But if this is so, what are we to do with biblical evil spirits? Here, A light shining in dark places is in tune with Thomas Hobbes' etymological analyses of the scriptural terms that were applied to the Enemy for centuries, as well as with Leviathan's exegetical strategies of naturalization and metaphorization of biblical passages concerning demons. Hobbes affirms that in the Bible, "spirits" may refer to (a) substances; (b) metaphors; (c) "an office, or quality"; (d) diseases; or (e) mental images. First, as we saw, Hobbes believed that the Scripture forces us to acknowledge the existence of evil spirits; but nothing forbids us to affirm that these are corporeal substances. Second, an evil spirit may stand, in a metaphorical sense, for a disposition or inclination: an "unclean spirit" refers to an evil disposition (Hobbes 2012, p. 208). Third, etymology shows us that "Satan", "Devil", "Abaddon", and "angel" are offices and qualities (respectively, "enemy", "accuser", "destroyer", "messenger"); these biblical terms, which should have never been left untranslated by the theologians, address not substantial spirits, but earthly human enemies of the Kingdom of God, or God's messengers (Hobbes 2012, pp. 213, 244). Fourth, several instances in which the Bible uses the word "spirit" could be interpreted simply as the way in which Pagans, Jews, and early Christians, ignorant of natural causes, understood mental diseases (Hobbes 2012, p. 208). Finally, we may think of "spirits" as mental images; that is, the product of a deceptive sense perception, dreams, and visions (Hobbes 2012, p. 210).

Koerbagh favors Hobbes' interpretation of biblical spirits as metaphors, natural diseases, earthly enemies, and messengers. This is evident in his etymological critique. For him, as for the English thinker, the clergy is at fault in not translating Satan, devil, or Abaddon, words that mistakenly imply

7 The interrogators asked Koerbagh about his relationship with Spinoza: "He admitted to having spent some time with Spinoza, to having gone to his home on different occasions, but he had never spoken of this affair with him ( ... ). [He] affirms that he never spoke of this doctrine [Biblical exegesis] with Spinoza" (quoted in (Nadler 2011, p. 44)). 
that the Scripture is speaking of proper names, or, as Koerbagh puts it, of "spirits in particular". As Leviathan contends, these terms refer to actions or dispositions. Note that Koerbagh-as he had already done in his 1668 dictionary, A flower garden-proposes accurate translation as a way to enlighten the general public: if theologians do not wish to give the proper meaning of the biblical text, Koerbagh will, "so that the common people may arrive at an understanding of such matters" - and once this is achieved, that they may reject Christian demonology altogether (Koerbagh 2011, pp. 422, 453).

Diaboloi, for example, is Greek for "slanderers", "accusers", "deceivers". Satan is Hebrew for "adversary or opponent", and "resister". In addition, while the theologians repeat that Satan or diaboloi "can only be said of evil spirits", the Scriptures also uses them to refer to "good spirits" and "people". In the same line, the term Abaddon means "destroyer, disrupter", and it is said, says Koerbagh, not of "fabricated evil spirits", but of "evil people ( ... ) destroying and disrupting [the] peace". The same holds true for "angels" (aggelos), which means "messengers", and that we should apply to "human messengers". Koerbagh also points out that, in the Bible, the devils "carry the name of several evil actions they perform". The Greek word diaballein, for example, means "speaking evil, blaming, accusing, informing, gossiping, and deceiving" (Koerbagh 2011, pp. 422, 425, 429).

$\mathrm{He}$ also analyzes the Greek word daimon. An ambiguous term to say the least, it can mean "God", "wise", "a hero or famous person", and a "hellish" or a "heavenly" god. The Greeks, "full of superstition", said that these daimones could also be spirits "good or evil". It is on these "fictions and nonsense" that Christian theologians rely-although, here, the clergy adds something of their own: that demons are "disembodied spirits ( ... ) evicted from heaven", a notion alien to the Pagans. Be it as it may, since the Greeks "never provided any clear proof" of the existence of these spirits, Koerbagh favors an alternative meaning for daimon: "the inborn nature of man". Thus, "someone with a good nature also has a good soul or spirit, and ( ... ) one with a bad nature also has a bad soul or spirit". From this word one can also derive daimonân, which stands for being "senseless, insane, or mad and raving" (Koerbagh 2011, pp. 433, 435). As we may see, etymology reinforces Koerbagh's strategy of naturalization and metaphorization of Biblical passages concerning devils: they are evil humans, evil dispositions, or mental disorders.

Let us now turn to Koerbagh's interplay between etymology, exegetical strategy, and Cartesian metaphysics. Matthew 4:1-11 records that "the devil", "Satan", appeared to Jesus in the wilderness, and took him to a high mountain in order to tempt him. It is worth noting that Hobbes analyzes the same story (adding Luke's version, 4:1-13), claiming that demonic temptation happened in Jesus' spirit, as a vision (Hobbes 2012, p. 354). Koerbagh agrees, at least in part: the demonic temptation comes not from without, it happens not outside Jesus' mind, but inside of him. This follows from his Cartesianism: being thought, "a spirit cannot lead someone away or take him somewhere and lead him to a high mountain". Clearly, theologians cannot use this passage as proof of the existence of a devil named Satan. What is Matthew saying, then?

It is true that I deny that there are such evil spirits as the clergy say there are, but I have not denied that there can be evil thoughts by which someone can be assailed as if by evil spirits, because thoughts spring from the mind. (Koerbagh 2011, pp. 235-37)

This implies a radical turn regarding Hobbes' interpretation: since metaphysics indicates that "evil spirits" may simply mean "evil thoughts", the passage does not evoke Jesus' vision, but a metaphor, a representation of his inner battle. "There was a mental struggle in his mind", between preaching the truth with no regard for his own safety, and a "strong desire for vain worldly status, or money" (Koerbagh 2011, p. 237). ${ }^{8}$ But what about Satan? Koerbagh's reading is again far more radical than Hobbes', and resulting in a highly heterodox version of Christ's demonic temptation: since "Satan", as we saw, can be translated as "adversary" or "tempter", this term may allude "to one of the closest

8 Koerbagh insists on this idea later on: if the word diaboloi means "accusers", who is the most powerful accuser at God's disposal? Not "any fabricated evil spirits", certainly, but "someone's own conscience" (Koerbagh 2011, p. 422). 
friends of the Saviour", an Apostle. Before Jesus went to the desert, one of his followers could have tried to convince him of giving up his dangerous mission. This may have given Jesus doubts: "there arose in his mind, asked when he was alone, such a struggle as we have described" (Koerbagh 2011, pp. 237,239$).{ }^{9}$

Let us see another example, the meaning of evil "angel". Koerbagh takes two passages, 2 Peter 2:4 and Jude 6, concerning angels who have erred and are punished by God. Hobbes quotes these verses in order to support his theory of angelic materiality against the scholastic notion of angels as "incorporeal substances": the passages, speaking about evil spirits being tormented or chained, show that "Angels (... ) are not thence proved to be Incorporeal"; they "prove the Permanence of Angelical nature", and "confirmeth also their Materiality" (Hobbes 2012, p. 213). However, we should note that a couple of lines above, quoting Matthew 25:41, Hobbes does suggest that these evil spirits could be, in fact, evil humans: "The name of Devil and his Angels may be understood of the Churches Adversaries and their Ministers" (Hobbes 2012, p. 213). Koerbagh is here, once again, more radical than Hobbes. Since his metaphysics forbids the existence of evil spirits as substances, he is not interested in debating the materiality or immateriality of "angels"; these passages clearly allude to human beings, and only to them. For example, 2 Peter 2:4: "God did not spare the angels when they sinned, but cast them into hell, and committed them to pits of nether gloom to be kept until the judgment". This passage is often incorrectly signaled as proof of "the fall of the spirits", an unwarranted assumption since nothing is said about evil spirits. The key word here is "angel": as we saw earlier, this means "messenger", and it refers, not to spirits, but to "human messengers" (Koerbagh 2011, p. 427). Peter wrote about angels who erred, which can be interpreted as "prophets or teachers who go astray". The passage, thus, speaks of

angels who said that they came on the orders of God to the people to proclaim their message, but who erred, that is, lied, which is not from God, and that God did not spare them but threw them into hell or down below, that is, cast them out or rejected them and delivered them to the chains of darkness, that is, to the lie, so as to be kept until judgement. (Koerbagh 2011, p. 349)

The same reading could fit Jude 6, which states that the "angels" who erred have been kept by God "in eternal chains in the nether gloom until the judgment of the great day". Koerbagh insists that the passage, contrary to what the Christian tradition says, "is not about devils, but about teachers in error". In this way, his interpretation of a demonological passage gives way to a theologico-political diatribe, a secularized demonization indeed: A light shining in dark places uses Jude 6 to pour scorn on the "leaders" of religion, the theologians, who had abandoned the light "and for political gain become seducers instead of leaders". Hence, whereas Jude 6 does not offer "proof of any evil spirit", it gives us "proof of evil human beings" who will be kept by God in darkness, "that is, false teachings" (Koerbagh 2011, pp. 427, 429).

As we can see, although Koerbagh displays a Hobbesian biblical exegesis based on an etymological interpretation of the scriptural evil spirit, his Cartesian metaphysics applied to Revelation seems more radical than Hobbes' materialism, not only rendering the operations of incorporeal spirits impossible, but denying that biblical evil spirits could exist as substances. On the overall subject of the biblical devil, Koerbagh concludes:

Since we have not been able to discover from all the names found in holy scripture that there are such evil spirits as the theologians invent, neither from the book on the origins nor any

9 It is interesting to point out that Koerbagh uses this idea to draw a parallel between him and Jesus: "If someone asks me how I dare consider a friend or acquaintance [of Jesus] as the tempter, I would answer that I read that his friends and those near to him slandered and scolded him, calling him mad and out of his mind. And such things still occur, since it has happened to me that all my friends have slandered and scolded me for being a fool and godless, and the like, though I, O! cruel slander, have never in my life written anything against reason, but have opposed that which is against reason" (Koerbagh 2011, p. 239). As we will see below, Koerbagh thinks that salvation means only to teach others true knowledge; that is, true "rational" religion—-that was what Jesus, "the savior", did (Koerbagh 2011, p. 143). 
other place in holy scripture, as has been said and proved, we rightly reject the fabricated evil spirits as well. (Koerbagh 2011, p. 451)

\section{A Light to Unveil Demonic Possession}

If disembodied spirits cannot intervene in the material world, and if scriptural "evil spirits" are non-existent and can be accounted for as inner natural dispositions, inner thoughts, and human enemies, what does Koerbagh think of demonic possession? In a nutshell, the state of possession is related to diseases, extraordinary but natural behavior, and evil thoughts. This interpretation appears in Hobbes' Leviathan, in which every biblical instance of demonic possession is read as a natural process or as metaphor. For example, since "the spirit of man, when it produceth unclean actions, is ordinarily called an unclean spirit", the Scripture may deploy this inclination to evil, metaphorically, as a demonic possession; thus, for example, the "entrance" of Satan in a man could be understood as "the wicked Cogitations, and Designes of the Adversaries of Christ, and his Disciples" (Hobbes 2012, pp. 38, 355). Likewise, as the biblical term "spirit" may stand for an extraordinary bodily passion, such as a mental disease, "Mad-men are said to be possessed with a spirit". Thus, it is clear that the Bible refers to "Mad-men, or Lunatiques" as "Daemoniaques" (Hobbes 2012, pp. 208, 211).

However, let us also note that Leviathan's materialism led Hobbes to deny the possibility of demonic possession precisely because he affirmed the existence of evil spirits: if "incorporeal substance" is an oxymoron, and spirits are bodies, then it is impossible to conceive a substance penetrating another substance. The fact that Hobbes admits spirits as substances explains why he rejects possession:

I have not yet observed any place of Scripture, from whence it can be gathered, that any man was ever possessed with any other Corporeall Spirit, but that of his owne, by which his body is naturally moved (... ). I find that there are Spirits Corporeall, (though subtile and Invisible); but not that any mans body was possessed, or inhabited by them. (Hobbes 2012, pp. 354-55)

Again, although Koerbagh's exegesis admits a Hobbesian naturalization and metaphorization of biblical possession, his metaphysics led him to a far more radical account of this subject. Let us start with his etymological analysis. A light shining in dark places devotes several paragraphs to analyze the Greek word which, in the New Testament, expresses the state of being possessed, daimonizestai. As a derivation of daimon, its meaning could be "being placed among the gods, or being counted as gods, or being turned into a god" (Koerbagh 2011, p. 433). On the other hand, as the word daimon can refer to either a good or a bad spirit, daimonizestai can also mean "being guided by a good spirit as well as being plagued by an evil spirit". This is in line with Koerbagh's preferred meaning for daimon, "the inborn nature of man". Thus, "it is certain that someone with a good nature also has a good soul or spirit, and that one with a bad nature also has a bad soul or spirit". Should someone look for a "reasonably clear explanation" for possession, one would need only to "apply a good spirit to someone's good nature and an evil spirit to an evil nature" (Koerbagh 2011, p. 435).

In this context, a demonic possession could be interpreted through metaphorization and naturalization. Daimonizestai may be read as "being plagued by an evil spirit", because, as Cartesianism shows, spirit is thought, and "thoughts are workings of the mind, that is of the soul". The cause of the suffering, then, is spiritual, but it is internal rather than external: those who are daimonizestai "are not plagued by an evil spirit coming from outside, as the theologians think, but by an evil or defective soul". This, in turn, could be the result of physical impairments, such as "poor constitution of the blood" and "weakness of the brain" (Koerbagh 2011, p. 433). Furthermore, Koerbagh is explicit in the Spinozist equation of God and natura. Because God is the essence of all his modes of being, it could be said that all things—bodies, thoughts, diseases, events—are God's messengers (Wielema 2003b, p. 74). It seems appropriate, then, to think that "someone is punished or plagued by God" with an evil spirit, because "various diseases with which we are often visited by God are evil spirits, and furthermore all sorts of evil thoughts". In one of his most monistic paragraphs, Koerbagh affirms that daimonizestai can 
be interpreted as "being tortured or plagued by God, namely by madness, insanity, epilepsy, lunacy, or evil thoughts" (Koerbagh 2011, p. 433).

As this state often results in "being out of one's senses", it produces symptoms that are commonly attached to demonic possession. Koerbagh happens to list symptoms found in the Bible, but without mentioning any scriptural passage: being mute and blind (Matthew 9: 33; 12: 22), falling down (Mark 9: 18, 20), not hearing (Mark 9, 25; Matthew 12: 22): ${ }^{10}$

When someone catches one of the described diseases, he becomes so witless or out of his mind that he falls down and does not see or hear, as happens with such afflictions, or so out of his wits that he says strange things which he has no recollection of having said. (Koerbagh 2011, p. 433)

But why is this confusion between demonic possession and natural affliction so common? Here, we may detect Hobbes' influence. Leviathan affirms that ignorance of natural causes led Pagans and Jews to take as possessed people those madmen and lunatiques "or [those] that spoke anything, which they for want of understanding, thought absurd" (Hobbes 2012, p. 353). Koerbagh follows this explanation: "those who were plagued by rage or madness sometimes did and said curious and absurd things for which the common people could not give an explanation or provide a cause" (Koerbagh 2011, p. 437). As his analyses on devils and daimonizestai prove, this cause has nothing to do with diabolical spirits; for Koerbagh, being possessed simply means that one suffers at the hands of natura and of human nature.

Let us see an example of Koerbagh's exegesis concerning a biblical case of possession and exorcism, Matthew 12:22 and 24. He quotes Matthew 12:22: "Then a blind and mute demoniac was brought to him, and [Jesus] healed him, so that the man spoke and saw". He starts by pointing out that daimonizomenos, translated here as "demoniac", comes from daimonizestai, the state of being plagued by evil spirits-i.e., by evil thoughts or physical ailments. The best reading of the passage would be: "Then was brought to him one who was miserable (or crazed) being blind and deaf, or deaf mute" (see note 11 above); and later: "And he cured him so that the blind and deaf mute spoke and saw" (Koerbagh 2011, p. 441).

This opens Koerbagh's discussion on exorcism. Witnessing this cure, the Pharisees thought that Jesus was in league with the devil, who gave him the power to exorcize: "This one does not throw out the devils unless through Beelzebub, lord of the devils" (Matthew 12: 24). Nevertheless, Koerbagh affirms that Matthew 12:22 says nothing about an exorcism:

It does not say "throw out", as is stated in [Matthew 12:] verse 24, as if one could throw out a spirit as a hand throws a stone. Instead, it says here that the Saviour cured the sick or miserable man of his afflictions. (Koerbagh 2011, p. 443)

Koerbagh develops his interpretation of Matthew 12:24 by analyzing the Pharisees' accusation that Jesus exorcized through the power of the devil. The passage, Koerbagh contends, says nothing about "devils": it speaks of daimonian; that is, gods or evil spirits. The reading of the passage should thus be "This does not throw out the evil nature (or deficient nature; that is, deficiencies, namely of people) unless in the lord of the flies, highest (that is helper) of the evil natures". What could this mean? With a keen sense of the importance of history and culture for an adequate interpretation of the biblical text, Koerbagh points at Pagan religious praxis. The heathens used to ascribe a "special god", a "patron helper" so to speak, to every given sickness. Beelzebub, "the lord of the flies", was one of them, "a patron or helper in some mental deficiencies". This was known by the Pharisees, and provided the substance of their accusation to Jesus, i.e., that he was as an impious Jew:

10 Let us point out that Koerbagh stresses that Matthew 12:22 is not about a blind and mute demoniac, but a blind and deaf one: the biblical word "kophos" does not mean "mute", as traditional translations have it, "but deaf, and deaf from birth, which is put together in Dutch in a fine expression, namely deaf mute" (Koerbagh 2011, p. 441). 
Wishing to portray the Saviour (although they knew that he was a Jew) as a heathen and scold him, [the Jews] said in their slander: 'He does not throw out the evil natures (or deficiencies) except in the lord of the flies, chief of evil natures (or miseries, or miraculous things, as the word daimonia can also be interpreted), that is, he helps in the name of an idol (whom the heathens claim to be a helper in several specific troubles or miseries) and not in the name of the true God. (Koerbagh 2011, pp. 439-41)

Since Koerbagh rejects the notion of exorcism (he speaks about the "cure" of a natural affliction), his detailed analysis of the passage betrays an interest in highlighting the cultural context in which the Jews and Christ used to live. The religious practices of the Pagans allowed the Jews to cast Jesus as an idolater, denying him the power to exorcize in the name of God, and instead accusing him of exorcizing in the name of a demon. In this same line, Koerbagh adds, Matthew 12:24 should not be taken as a biblical proof of the existence of demons and the possibility of exorcism, because the Pharisees "did not speak as wise and learned people but as superstitious heathens and Greeks, whose way of speaking they used" (Koerbagh 2011, p. 439). Scripture, then, seems to teach us nothing about metaphysics, but a great deal about the mental world of their authors. In the concluding section, we shall see why this insistence on the culture of the biblical world is crucial to understanding the implications of Koerbagh's denial of demonic possession and demonology.

\section{The Devil, from Sacred Truth to Cultural Heritage}

After this account on the philosophical and exegetical assault on spirits, demons, and demonic possession in the thought of Adriaan Koerbagh, it should be clear why the second half of the XVIIth century provided the most coherent attack on the medieval and early modern idea of the devil that Europe had ever met until that moment. The anonymous 1691 Dutch poet with whom we opened this article was indeed right when he related Balthasar Bekker's De Betoverde Weereld to Thomas Hobbes and Koerbagh. Anyone reading Bekker's work will immediately encounter the same strategies of naturalization, metaphorization, and a critical use of etymology regarding the interpretation of biblical devils and instances of demonic possession. Of course, Hobbes's Leviathan and Bekker's anti-demonological synthesis cannot be compared with Koerbagh's book in terms of actual impact in the debate about devils and demons, given that $A$ light shining in dark places remained an unknown oeuvre for centuries. But that should not deter us from stressing the radical nature of Koerbagh's views on the subject. His biblical interpretation, armed with Greek and Hebrew etymology, natural afflictions, and figures of speech, provided alternative explanations for those key passages concerning demons. This, I think, was developed under an important Hobbesian influence. Nevertheless, whereas Hobbes taught that Revelation commands us to believe in the devil's existence, and that materialism shows us that spirits must be substances-and thus real entities-Koerbagh's definition of spirit entailed the metaphysical impossibility of the existence of the devil and the experience of spiritual possession. Koerbagh's Cartesianism, then, far surpassed Hobbes' materialism; thus, at least from the anti-demonological point of view, radicalism was indeed on the side of the early Dutch Enlightenment.

Thus, we may highlight Koerbagh's role in the intellectual history of the critique of the Christian devil, and his place in the proto-Enlightenment equation between demonology and superstition. Along this line, I wish to employ this last section to entertain a further thought on his perceptions regarding these affinities between superstition and belief in demons. As Wiep van Bunge notes, decades before Bekker entered the early Enlightenment scene, demonic intervention had already been ridiculed as the product of philosophical, theological, and philological error (Van Bunge 1995, p. 50). As may be gathered from what we wrote in the preceding sections, Koerbagh had the intention to extirpate the Christian devil from true religion, thus curtailing the role of demonology in the economy of the sacred. My question here is in which way is this anti-demonological project connected with the Enlightenment gesture towards the secularization of Scripture. In this specific case, I am interested in the overall impact of the naturalistic and historical reading of biblical passages concerning the Enemy, and their relationship (or lack of) with the Christian truth. 
Hobbes is, again, of some importance if we want to understand this. Given that, as we saw, biblical demonic possession is a metaphor or an illness, why did Christ heal as if he was exorcizing demons? Jesus' exorcisms are an example of divine accommodatio: the message that God wishes to convey must be uttered in the language of men, i.e., adapted to their capacities. Thus, Christ commanded "the Madnesse, or Lunacy he cureth" as if they were devils, because people at that time believed that natural afflictions were instigated by evil spirits (Hobbes 2012, p. 354). Does this make Jesus a liar? Why would the Savior, who is the Truth, trick us? All this discussion, Hobbes affirms, is a matter "more curious than necessary for a Christian mans Salvation". To debate the possibility or impossibility of possession is futile. True Revelation tells us that demons exist; nevertheless, the only article of faith that matters for salvation is that Jesus is the Christ, who promises a future Kingdom and immortality for those who believe in him. Thus, "the opinion of Possession by Spirits, or Phantasmes, are no impediment in the way" of salvation; furthermore, it could be a dangerous occasion for men "of going out of the way, and to follow their own Inventions" (Hobbes 2012, p. 355). In addition, Revelation teaches us nothing about natural philosophy: Christ only spoke about the fundamental principles of salvation, "leaving the world, and the Philosophy thereof to the disputation of men, for the Exercising of their natural Reason" (Hobbes 2012, pp. 38-39). Speaking explicitly about demonic possession, Hobbes contends that Jesus left "the search of natural Causes, and Sciences, to the natural Reason and Industry of men" (Hobbes 2012, p. 355). In conclusion, devils, their activities, and our understanding of them are indifferent regarding salvation.

We know that Koerbagh took a more radical turn than Hobbes, claiming that demons were not even part of Revelation. Revelation is not distinct from philosophy: the word of God is not above or against reason; it is reason, and if reason shows that there are not evil spirits as the theologians understand them, then Scripture must reflect this. Indeed, if read without prejudice and according to the literal meaning of the Hebrew and Greek original, the Bible does not support the belief in the existence of the devil (Wielema 2003b, pp. 65-66, 72). After his critical analyses on demons, Koerbagh asks:

Where in holy scripture is there such an explicit commandment as that those who do not believe that there are such fabricated evil spirits as the clergy invent will be forever doomed? Nowhere. (Koerbagh 2011, p. 451)

But we do hear Hobbes loud and clear when Koerbagh discusses the salvational value of belief in demons: devils are not "a matter of importance in which there is any salvation", and on this subject "one can believe or reject it as one chooses". Moreover, Koerbagh's idea of salvation clashes head on with demonology because, for him, salvation consists "in bringing one or many (the more, the greater the saviour) out of ignorance to knowledge, wisdom and understanding" - an interesting hint at the Spinozist moral commandment, "love your neighbor". This is the true "knowledge of God", which allows us to reach "life eternal" (Koerbagh 2011, pp. 143, 451). It is safe to say, given what we saw above about Koerbagh's interpretation of biblical evil spirits, that few things are further away from knowledge than the Christian idea of demons.

It seems clear, then, that Hobbes and Koerbagh share the view according to which, even when the Scripture mentions devils (or that which the theologians take for devils), they are not part of the fundamental sacred truth; quite the contrary, they are pernicious if one wishes to search for salvation. Let us go a step further and ask where, according to Hobbes and Koerbagh, did these devils and the belief in them came from in the first place. Leviathan provides an answer: the Pagan worldview. Given that the Pagans misunderstood nature's operations, they posit gods and daemones, invisible and powerful spirits, good or bad, to explain many natural events that they could not comprehend-for example, madness, which they attributed to demonic possession. Now, these Pagan daemones found their way first into Judaism, and then into Christianity (Hobbes 2012, pp. 51, 353). Indeed, says Hobbes, that which the Greeks called "Daemones", the Jews "called Spirits, and Angels, Good or Bad"; not even the Apostles escaped from this: "The Disciples themselves did follow the common opinion of both Jews and Gentiles, that some such apparitions were not Imaginary, but real" (Hobbes 2012, p. 210). These ideas concerning spirits did not change over time; on the contrary, the Christian religion 
inherited "the Daemonology of the Heathen Poets, that is to say, their fabulous Doctrine concerning Daemons" (Hobbes 2012, p. 334). In the hands of the clergy, themselves, part of a "confederacy of deceivers", this pernicious doctrine is still damaging the State and its subjects. And they are deceivers because demonology, that vital remnant of Paganism, is not part of true religion: "Men are the more easily seduced to believe the doctrine of Devils, which at that time was the Religion of the Gentiles, and contrary to that of Moses and of Christ" (Hobbes 2012, p. 244). Leviathan, itself, with its combination of natural philosophy, anthropology, biblical exegesis, and political theory, is Hobbes's attempt to free Christianity and the State from this dangerous belief.

Koerbagh is also explicit in relating Christian demonology to Paganism. The Greeks, "being heathens full of superstition", invented daimones; that is, gods, spirits, and spectres. Christianity took these entities at heart as evidence of the existence of the devil- "if we want to accept the Greek fictions and nonsense, then I admit that the theologians would already have some proof here". Under Koerbagh's eyes, many central elements of traditional demonology are only variations on Pagan themes. For example, the concept of hell derives from the "heathens poets" who, "often like clergy", devised "such terrifying fabrications" - in this case, Hades-in order to "scare the common people away from doing evil". We may expect this fiction, given that the poets of antiquity, "who often or usually took the place of theologians in ancient times", used to invent "many fantasies". Another example: the demonic serpent in the Garden of Eden may also have been of heathen origin. The whole story may come from that "incorrect way of speaking and writing that was quite common among the Egyptian priesthood, from whom Moses learned it and introduced it into the Jewish religion". Finally, and as we saw above, Koerbagh believed that the Pharisees's accusation against Jesus- that he exorcized in the name of Beelzebub - could not stand as proof of the existence of the devil precisely because "those who spoke there did not speak as wise and learned people but as superstitious heathens and Greeks". Indeed, "Greek superstitions"—in this case, the devil-“also took hold of the Jews" (Koerbagh 2011, pp. 341, 435, 439, 443, 449).

As we may see, Hobbes and Koerbagh strove for the elimination of many central aspects of early modern Christianity, labeling them as "superstitions" and treating them as alien to God's true message. What is truly divine in Scripture- "Jesus is the Christ" (Hobbes), "teach others true knowledge" (Koerbagh) - must be isolated from what is strictly the product of human invention. Pagan and Jewish languages and figures of speech, their legends and stories, and above all their ignorance of natural law and metaphysics, have swaddled the simple sacred message in layer after layer of philosophical, theological, and scientific error, i.e., in superstition. This has not been corrected by Christianity as organized religion; quite the contrary, theologians strengthened these errors. It is the mission of the true philosopher and the true Christian to rediscover the divine truth. This, I think, is what Koerbagh, and Hobbes before him, aimed at.

This fits well with Koerbagh's discussion on the biblical devil and the scriptural instances of demonic possession. For him, the early modern idea of the Christian devil rests on Jewish and Pagan superstition; etymology, metaphors, evil thoughts, human enemies, and shared erroneous beliefs about metaphysics and natural laws in the biblical world could better explain those passages mentioning demons and possession. For Koerbagh, and here he departs from Hobbes, this explanation entails that devils do not exist at all, that they are indeed "fictitious evil spirits". As we may conclude, in a process that could be referred to as the secularization of the biblical devil, late XVIIth-century anti-demonologies like the one advanced by Adriaan Koerbagh turned what once was a part of a sacred truth into a fragment of a human — and thus a feeble, transitory, and changeable—cultural heritage.

Funding: This research received no external funding.

Conflicts of Interest: The author declares no conflict of interest. 


\section{References}

Anonymous. 1691. De Betoverde Weereld van den Hooggeleerden Heer, Dr. Balthasar Bekker, Door de Geestelykheit bevogten. In Verscheyde Gedichten, Soo voor, als Tegen het Boek, Genaamt: De Betoverde Weereld. Gedrukt: Voor de Liefhebbers.

Attfield, Robin. 1985. Balthasar Bekker and the decline of the Witch-Craze: The old demonology and the new philosophy. Annals of Science 42: 383-95. [CrossRef] [PubMed]

Bath, Jo, and John Newton. 2006. 'Sensible Proof of Spirits': Ghost Belief during the Late Seventeenth Century. Folklore 117: 1-14. [CrossRef]

Cameron, Euan. 2010. Enchanted Europe: Superstition, Reason, and Religion, 1250-1750. Oxford: Oxford University Press.

Champion, Justin. 2012. 'The Kingdom of Darkness': Hobbes and Heterodoxy. In The Intellectual Consequences of Religious Heterodoxy 1600-1750. Edited by Sarah Mortimer and John Robertson. Leiden: Brill, pp. 95-120.

Del Olmo, Ismael. 2018. Against Scarecrows and Half-Baked Christians: Thomas Hobbes on Spiritual Possession and (Civil) Exorcism. Hobbes Studies 31: 127-46. [CrossRef]

Fix, Andrew. 1989. Angels, Devils, and Evil Spirits in Seventeenth-Century Thought: Balthasar Bekker and the Collegiants. Journal of the History of Ideas 50: 527-47. [CrossRef]

Fix, Andrew. 1999. Fallen Angels: Balthasar Bekker, Spirit Belief, and Confessionalism in the Seventeenth-Century Dutch Republic. Dordrecht: Kluwer Academic.

Gijswijt-Hofstra, Marijke, Brian P. Levack, and Roy Porter, eds. 1999. The Athlone History of Witchcraft and Magic in Europe: The Eighteenth and Nineteenth Centuries. London: Athlone Press, vol. 5.

Hobbes, Thomas. 1928. The Elements of Law: Natural and Politic. Edited by Ferdinand Tönnies. London: Cambridge University Press.

Hobbes, Thomas. 2012. Leviathan. Edited by Noel Malcolm. Oxford: Clarendon Press, vol. 3.

Israel, Jonathan. 1996. The Bekker Controversies as a Turning Point. Dutch Crossings 20: 5-21. [CrossRef]

Israel, Jonathan. 2001. Radical Enlightenment: Philosophy and the Making of Modernity 1650-1750. Oxford: Oxford University Press.

Jobe, Thomas. 1981. The Devil in Restoration Science: The Glanvill-Webster Witchcraft Debate. Isis 72: 342-56. [CrossRef]

Jongeneelen, Gerrit. 1991. La Philosophie Politique d'Adrien Koerbagh. Cahiers Spinoza 6: 247-67.

Koerbagh, Adriaan. 1668. Een Bloemhof van Allerley Lieflijkheid Sonder Verdriet Geplant door Vreederijk Waarmond Ondersoeker der Waarheyd. Amsterdam: n.p.

Koerbagh, Adriaan. 2011. A Light Shining in Dark Places, To Illuminate the Main Questions of Theology and Religion. Edited by Michiel Wielema. Leiden: Brill.

Lilti, Antoine. 2009. Comment écrit-on l'histoire intellectuelle des Lumières? Spinozisme, radicalisme et philosophie. Annales. Histoire, Sciences Sociales 64: 171-206.

MacMillan, Alissa. 2014. Exorcizing Demons: Thomas Hobbes and Balthasar Bekker on Spirits and Religion. Philosophica 89: 13-48.

Malcolm, Noel. 2002. Aspects of Hobbes. Oxford: Clarendon Press.

Nadler, Steven. 2011. A Book Forged in Hell: Spinoza's Scandalous Treatise and the Birth of the Secular Age. Princeton: Princeton University Press.

Salatowsky, Sascha. 2017. Socinian Headaches: Adriaan Koerbagh and the Antitrinitarians. In The Dutch Legacy: Radical Thinkers of the 17th Century and the Enlightenment. Edited by Sonja Lavaert and Winfried Schröder. Leiden: Brill, pp. 165-203.

Schaffer, Simon. 1985. Occultism and Reason in the Seventeenth Century. In Philosophy: Its History and Historiography. Edited by Allan Holland. Dordrecht: Reidel Publishing, pp. 117-43.

Spinoza, Baruch. 1995. The Letters. Edited by Steven Barbone, Lee Rice and Jacob Adler. Indianapolis: Hacket Publishing Company.

Spinoza, Baruch. 2002. Complete Works. Edited by Michael Morgan. Indianapolis: Hackett Publishing Company. Spinoza, Baruch. 2007. Theological-Political Treatise. Edited by Jonathan Israel. Cambridge: Cambridge University Press. Springborg, Patricia. 2004. The Enlightenment of Thomas Hobbes. British Journal for the History of Philosophy 12: 513-34. [CrossRef] 
Van Bunge, Wiep. 1995. Eric Walten (1663-1697): An Early Enlightenment Radical in the Dutch Republic. In Disguised and Overt Spinozism Around 1700: Papers Presented at the International Colloquium, Held at Rotterdam, 5-8 October 1994. Edited by Wiep van Bunge and Wim Klever. Leiden: Brill, pp. 41-54.

Van Bunge, Wiep. 2000. Du Betoverde weereld au Monde enchanté. Traces de Bekker dans les premières Lumières françaises. In Materia Actuosa. Antiquité, âge classique, Lumières. Mélanges en l'honneur d'Olivier Bloch. Edited by Antony Mckenna, Miguel Benítez, Gianni Paganini and Jean Salem. Paris: Honoré Champion, pp. 453-71.

Van Bunge, Wiep. 2001. From Stevin to Spinoza: An Essay on Philosophy in the Seventeenth Century Dutch Republic. Leiden: Brill.

Van Bunge, Wiep. 2011. Introduction. In A Light Shining in Dark Places, To Illuminate the Main Questions of Theology and Religion. Edited by Michiel Wielema. Leiden: Brill, pp. 1-38.

Van Ruler, Han. 2000. Minds, Forms, and Spirits: The Nature of Cartesian Disenchantment. Journal of the History of Ideas 61: 381-95. [CrossRef]

Vermeir, Koen. 2013. Mechanical Philosophy in an Enchanted World: Cartesian Empiricism in Balthasar Bekker's Radical Reformation. In Cartesian Empiricisms. Edited by Mihnea Dobre and Tammy Nyden. Dordrecht: Springer, pp. 275-306.

Waite, Gary. 2018. Knowing the Spirit(s) in the Dutch Radical Reformation: From Physical Perception to Rational Doubt, 1536-1690. In Knowing Demons, Knowing Spirits in the Early Modern Period. Edited by Michelle Brock, Richard Raiswell and David Winter. Cham: Palgrave Macmillan, pp. 23-54.

Wielema, Michiel. 2001. The Two Faces of Adriaan Koerbagh. Geschiedenis van de Wijsbegeerte in Nederland 12: $57-75$.

Wielema, Michiel. 2003a. Adriaan Koerbagh. In The Dictionary of Seventeenth and Eighteenth-Century Dutch Philosophers. Edited by Wiep van Bunge, Henri Krop, Bart Leeuwenburgh, Han van Ruler, Paul Schuurman and Michiel Wielema. Bristol: Thoemmes Press, pp. 571-74.

Wielema, Michiel. 2003b. Adriaan Koerbagh: Biblical Criticism and Enlightenment. In The Early Enlightenment in The Dutch Republic, 1650-1750. Edited by Wiep van Bunge. Leiden: Brill, pp. 61-80.

Wielema, Michiel. 2004. The March of the Libertines: Spinozists and the Dutch Reformed Church (1660-1750). Hilversum: Uitgeverij Verloren.

Wielema, Michiel. 2017. Abraham van Berkel's Translations as Contributions to the Dutch Radical Enlightenment. In The Dutch Legacy: Radical Thinkers of the 17th Century and the Enlightenment. Edited by Sonja Lavaert and Winfried Schröder. Leiden: Brill, pp. 204-26.

(C) 2019 by the author. Licensee MDPI, Basel, Switzerland. This article is an open access article distributed under the terms and conditions of the Creative Commons Attribution (CC BY) license (http://creativecommons.org/licenses/by/4.0/). 